\title{
A Speech Act Analysis of the Acceptance of Nomination Speeches of Chief Obafemi Awolowo and Chief M.K.O. Abiola
}

\author{
Samuel Alaba Akinwotu ${ }^{1}$ \\ ${ }^{1}$ Department of English Studies, Adekunle Ajasin University, P.M.B. 001, Akungba-Akoko. Nigeria \\ Correspondence: Samuel Alaba Akinwotu, Department of English Studies, Adekunle Ajasin University, P.M.B. 001, \\ Akungba-Akoko. Nigeria. Tel: 234-080-3361-2528. E-mail: saakinwotu@yahoo.com
}

Received: January 24, 2013

Accepted: April 4, 2013

Online Published: April 12, 2013

doi:10.5430/elr.v2n1p43

URL: http://dx.doi.org/10.5430/elr.v2n1p43

\begin{abstract}
This study investigates the role of language in the communication and interpretation of intentions by examining selected political speeches as pieces of discourse with specific goals. It presents and documents some of the significant illocutionary acts that convey the intentions of speakers in the acceptance of nomination speeches of presidential candidates in Nigeria. The acceptance of nomination speeches of Chief Obafemi Awolowo and Chief M.K.O. Abiola form the bulk of our data. The study is based on insight from J.L. Austin (1962) speech act theory. Five categories of speech acts identified by Searle's $(1969,1976)$ are significant in the speeches. They include assertive acts $(27.3 \%)$, expressive acts $(22.70 \%)$, commissive acts $(22.70 \%)$, directive acts $(18.2 \%)$ and declarative acts which account for $9.1 \%$ of the total data. The study has revealed that the acceptance of nomination speeches are characterised by illocutionary acts that are used to achieve persuasion. Hence, the data are characterised by a preponderance of assertive, expressive and commissive acts that are mostly used as mobilization strategies, especially in political campaigns, where it is essential for candidates to persuade their listeners to win elections. The acts performed in the speeches examined are essentially similar; however, they were encoded more explicitly by Chief Abiola than Chief Awolowo.
\end{abstract}

Keywords: Acceptance of nomination speeches, Intentions, Obafemi Awolowo, M.K.O. Abiola, Illocutionary act

\section{Introduction}

Studies on presidential speeches as an aspect of political discourse have been from wide range of perspectives. Undoubtedly, political discourse has been a major domain of language use that has attracted the interests of researchers for a long while. This is because political discourse is a complex human activity that deserves critical study particularly because of its central place in the organisation and management of society. Some scholars have examined the communicative strategies employed in political processes and the role of the media in the dissemination of political messages (See Bennett, 1981; King, 1976; Gronbeck, 1978; Ozimede, 1985; Moore, 1987 and McQuail, 1992). Skoniecki and College (2004) examine President Ronald Regan's of the United States of America's speech, calling for action against communism, to the people of West Berlin and the world. The speech, 'Tear Down this Wall' was delivered against the backdrop of the cultural history of the Americans and it culminates in the opening of the Berlin wall. The study shows the effectiveness of Regan's persuasive use of language in facilitating the opening of the Berlin wall. Bullock (2003) examines the rhetorical strategies employed by President Bush as means of persuasion for the prosecution of the Iraqi's war and to justify America's interest in prosecuting the war. In a related work, Rudyk (2007) examines power relations in Bush's union speech. The speech which focuses on the semantic, syntactic and pragmatic levels of manipulations, studies the abuse of power in the US-Iraqi war and its effects on the recipients. Pu (2007) investigates the deployment of linguistic and rhetorical strategies in Bush's speech at Tsinghua University, China.

In Nigeria, there are quite a number of scholarly contributions to the pool of studies on the language of politics. Adegbija (1988) investigates military coup speeches in Nigeria. The paper which focuses the deployment of discourse tact, reveals the effectiveness of discourse tact in ensuring that illocutionary force is achieved in discourse. Oha (1994) is a stylistic study of the war speeches of Yakubu Gowon and Emeka Ojukwu. The study, which probes into the nature and the relationship of style to meaning, examines how the conflict between the two sides is demonstrated in their use of language. Wiredu (1996) looks at style in the language of politics in Nigeria by focusing on the identification of the various persuasive strategies employed by politicians to sway the electorate. 
Also, Awonusi (1996) examines the discourse features and strategies in election campaign texts. The study focuses on how Nigerian politicians use advertisement to project their image to voters. Opeibi (2004) is a discourse study of the use of English in the 1993 presidential election campaigns in Nigeria. Opeibi examines how politicians use the English language for effective communication of their goals. Adegoju (2005) examines style in political conflicts in the June 12 crisis in Nigeria. The study accounts for the various ways language is used in defending and promoting personal and group interests and in subverting the goals of opponents. Ayeomoni (2005) is a linguistic stylistic study of some speeches of past Nigerian Military rulers. He observes that such speeches are replete with the use of punctuation marks such as comma and full stops as stylistic devices to show frankness, fearlessness and boldness.

Further still, Adetunji (2009) studies speech acts and rhetoric in the Second Inaugural Address of President Olusegun Obasanjo of Nigeria and President George Bush of America. The paper, which employs a combination of speech act and rhetoric, proves that two contextually contiguous speeches may not have similar illocutionary forces and rhetorical elements even when they belong to the same discourse genre. Babatunde and Odepidan (2009) examine the roles of pragmatics and rhetoric in effective communication in politics and governance. Using select speeches of President Olusegun Obasanjo as data, the paper explores the effects of context, intention and world knowledge on the choice of acts performed in the data. Okpanachi (2009) examines the structure of power struggle and the underlying ideologies in President Obasanjo's national address of 8th October, 2003, on the dispute between the Nigeria Labour Congress (NLC) and the Federal Government. The paper reveals how Obasanjo uses language as a weapon to categorise and portray the Nigerian Labour Congress (NLC) as an enemy of the state while portraying his government as patriotic; expressly championing the interest of the people. Significant as these contributions are, none has specifically characterised the acts performed in the acceptance of nomination speeches of presidential candidates in Nigeria. This paper fills this gap.

\section{The Data}

The data for this study are selected speeches of Chief Awolowo (Presidential candidate of the Unity Party of Nigeria -UPN- in 1979) and Chief Abiola (Presidential candidate of the Social Democratic Party -SDP- in 1993). They were speeches accepting their nominations as the presidential candidates of their political parties. The speeches belong to the non-spontaneous category of oral speeches. In other words, they were formally prepared for oral delivery. Chief Awolowo's speech was published in a collection of his speeches titled Path to Nigerian Greatness (1986), while Chief Abiola's speech was published in his election campaign publication titled Hope '93: Farewell to Poverty (1993). Of particular importance are the communicative goals and the contexts of these speeches. The details of the speeches are presented in the table below:

Table 1. Details of the data analysed

\begin{tabular}{lllll}
\hline Text & Speaker & Topic & Setting & Date \\
\hline 1. & Chief Obafemi Awolowo & The challenges of the new era & UPN National Convention, Lagos & $6 / 10 / 78$ \\
2. & Chief M.K.O. Abiola & Hope for Nigerians & SDP National Convention, Jos & 29/03/93 \\
\hline
\end{tabular}

\section{Theoretical Orientation}

The study of meaning as an enterprise in language study has attracted a lot of enquiries from various language experts. So far, two major directions have been distinguished; these are semantics and pragmatics. Although these perspectives are different, they are complementary. Semantics as the third branch of linguistics has been defined as "the study of meaning". According to Yule (1997:114), in semantic analysis, there is always an attempt to focus on what the words conventionally mean. Thus, semantics studies the conventional meaning conveyed by the use of words, phrases and sentences of a language. Pragmatics, on the other hand, is often described as the study of language in use. Kempson (1986:251) defines pragmatics as "the study of the general cognitive principles involved in the retrieval of information from an utterance." In the same vein, Watson and Hill (1993:146) describe it as "the study of language from the point of view of the user, especially the choices, the constraints he meets with in employing the use of the language and the effects the use has on the communication situation." The difference, however, is that "while in semantic analysis, there is an attempt to focus on what the words conventionally mean, pragmatic analysis focuses on what a speaker might want the words to mean on a particular occasion" (Yule 2003:114). Thus, meaning in pragmatics is defined relative to a speaker or user of the language, whereas meaning in semantics is defined purely as a property of expressions in a given language, in abstraction from particular situations, speakers or hearers (Leech 1983:6). Goddart (1998:15) clearly defines pragmatics as "the study of how speakers and hearers interpret meaning in particular context -taking account of the physical and social situation, knowledge of each other's background and cultural conventions..." 
Central to Pragmatics is Speech Act Theory, (henceforth SAT), as it is concerned with specific social acts performed in making utterances. SAT is traced to the view expounded in J.L. Austin's seminal publication, How to Do Things with Words (1962). Austin proves that there are many utterances whose production constitutes, partly or wholly, the performance of an action. He began his theory by distinguishing between performative and constative utterances. However, in a later development, he classified linguistic acts into three components. First, the locutionary act is the act of saying something. Second, there is Illocutionary act, which is an act performed in saying something e g. promising, naming, requesting, etc. It is the intention the speaker has in uttering a statement. The third is perlocutionary act, which acts on the addressee, i.e. the response of the listener on his/her understanding of the illocutionary force of an utterance.

Illocutionary act is central to SAT. In fact, SAT has become synonymous with illocutionary act. According to Thomas (1995:51) "illocutionary Act, illocutionary force, pragmatic force, or just Force are used to mean the same thing because the communicative purpose of utterance has been seen as the focal point in the performance of SA". Illocutionary act has been categorized variously. Austin (1962) categorized it into five classes -verdictives, exercitives, commissives, habitives and expositives. However, he has been criticised on the basis of his claim that English verbs correspond to these SA categories. Hence, Searle $(1969 ; 1976)$ modified this classification upon the recognition of the illocutionary force of utterances. His classification is as follows:

i. Assertives: Commit speakers to the truth of some proposition e.g. stating, claiming, reporting, announcing, etc.

ii. Directives: Count as attempt to bring about some effect through the action of hearer e.g. requesting, ordering, demanding, begging, etc.

iii. Expressives: Count as the expression of some psychological state e.g thanking, apologising, congratulating, etc.

iv. Commissives: Commit speakers to some future action e.g promising, offering, swearing, etc. to do something.

v. Declarations: Speech acts whose successful performance brings about the correspondence between the propositional content and reality. e.g naming a baby/ship, resigning, dismissing, accepting, etc.

We adopt Searle's classification for the purpose of analysis in this paper.

A number of discourse situations manifests in the performance of social acts in different contexts of interaction, especially with respect to English usage. Political communication involves a focus on meaning, the understanding of which is largely a function of reaching the illocutionary force of a speaker's utterances. Usually, politicians seek to mould public perception of themselves and their programmes, and elicit support through their political speeches and campaign activities, symbolic appeals and various rhetorical strategies. However, the ability of the electorate to interpret rightly the political messages and intentions of the politicians and then respond appropriately is a function of how effective these candidates are in deploying the linguistic facilities available to them. Politicians articulate a lot of intentions in their speeches: they inform, inspire, assure, accuse, promise, direct, suggest, incite, apologize, disagree, criticize, etc. This underscores the relevance of SAT to our data analysis. We therefore focus our attention on the examination of the five major classes of illocutionary acts in the speeches. Further still, the analysis of a speaker's language use for persuasion and effective communication involves the context of utterance; hence, we make recourse to the contextual backgrounds that influence specific illocutionary acts when the need arises.

\section{Data Analysis}

The data has revealed that assertive acts accounts for the largest proportion with $27.3 \%$ of the illocutionary acts performed in our data. Next to this are expressive and commissive acts each accounting for $22.70 \%$. Directive and declarative acts account for $18.2 \%$ and $9.1 \%$ respectively. The summary of the illocutionary acts performed in our data is presented in the table and the chart below.

Table 2. Summary of the illocutionary acts in the data

\begin{tabular}{lll}
\hline Acts & Frequency & Percentage \\
\hline Expressive & 10 & $22.7 \%$ \\
Assertive & 12 & $27.3 \%$ \\
Commissive & 10 & $22.7 \%$ \\
Directive & 08 & $18.2 \%$ \\
Declaration & 04 & $9.1 \%$ \\
TOTAL & 44 & $100 \%$ \\
\hline
\end{tabular}




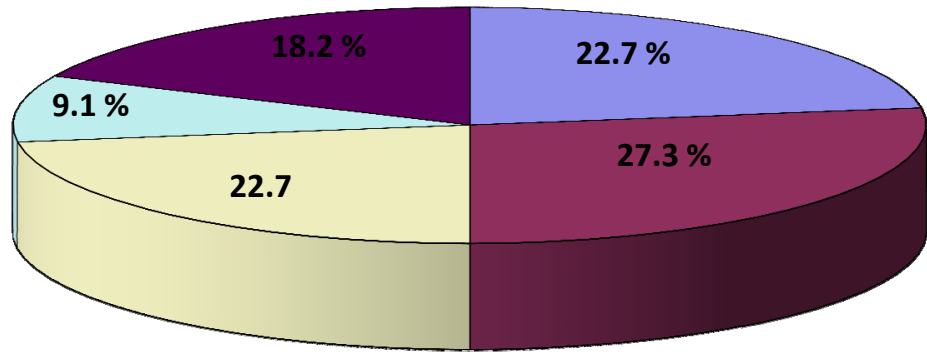

$\square$ Expressive

Assertive

$\square$ Commissive

$\square$ Declaration

Directive

Figure 1. Percentage Distribution of Illocutionary Acts in the Data

The reason for the preponderance of assertive, expressive and commissive acts is because our data are speeches accepting candidates' nomination as presidential flag bearers of their parties. Generally speaking, the specific speech acts performed in our data can be composed of as thanking the party delegates, assuring, encouraging, informing and promising them of better things to come and accepting their nomination. Let us now discuss in detail the performance of each of these acts in our data.

\subsection{Expressive Acts}

As earlier stated, expressive acts perform the function of revealing the psychological state of the speakers about the state of affairs which the illocution presupposes. Expressive act is often used to communicate speaker's intention in relation to the situation. Expressive acts in our data include thanking, praising, encouraging, inspiring, and assuring, and they account for $22.7 \%$ of the utterance acts in our data. Let us consider the following extracts:

\section{Extract 1}

I am most grateful to all of you for the unqualified honour you have done me by nominating me as the presidential candidate of the Unity Party of Nigeria for the coming election in 1979 (Text I)

\section{Extract 2}

I do sincerely hope we will succeed not only at the presidential election but also at the other preceding elections (Text I)

Extract 3

Enough of despair and despondency; this must be our season of hope and renewal. (Text II).

\section{Extract 4}

... I doff my hat for your doggedness and determination to fight against

all odds and for being a beacon of hope to Nigerian womanhood (Text II).

\section{Extract 5}

I know that together, we can replace cynicism with confidence; we can replace disillusionment with optimism...I want your support to banish the thinking that our beloved country cannot know real development and prosperity in our lifetime. (Text II)

The attitude of Chief Obafemi Awolowo is not hidden in extract 1 . He expresses appreciation to party delegates for his nomination as their presidential candidate. In this extract, the adjectives grateful and unqualified describe his 
state of mind. He is happy that he has been nominated the presidential candidate of his party. He raises the hope of his listeners to succeed in the elections in extract 2. The adverb sincerely and the verbs hope and succeed capture this. He performed the illocutionary acts of inspiring and assuring.

In extract 3, Chief M.K.O. Abiola demonstrates that he is unhappy with the general attitude of despair and despondency displayed by the people. Thus, he inspires and encourages his listeners towards developing the positive attitude of hope and renewal.

In a political landscape dominated by men, it is a natural thing to praise an only woman (Serah Jibril) who against all odds raises her head to slug it out with men. Chief Abiola performs the act of praising in extract 4 by acknowledging the doggedness of this woman.

The illocutionary force of extract 5 is encouraging. The speaker performs this act when he says I know that together, we can replace cynicism with confidence; we can replace disillusionment with optimism. The plural collective pronoun we (repeated twice) and the modal auxiliary can (indicating possibility) support the clause, I know that together, to encourage the listeners. This is a technique, called plain folks (Wiredu, 1996), used by politicians to identify with the audience they wanted to reach as a way to show that they (politicians) recognize and appreciate their contributions. The last sentence in the extract has the force of inspiring. The speaker hereby inspires his listeners to continue to support his mandate by making them feel important in the realization of his objective (winning the election). This is what he wants to achieve when he says I want your support to banish..., which implies that the objective cannot be realized without them.

\subsection{Assertive Acts}

Assertive act is the most common illocutionary act in our data representing $27.3 \%$ of the total utterance acts performed in the data. Assertive acts in our data include stating, suggesting, describing, claiming and informing. While some are indicated by the appropriate use of assertive verbs, others are inferred from the meanings of the sentences. Let us consider the following extracts:

\section{Extract 6}

This is a time of great difficulty and uncertainty, a time of the most daunting challenges. (Text I)

\section{Extract 7}

I make bold to say fellow compatriots that government is a serious business

and if we hope to get out of our grim economic predicament, we must of

necessity, employ the fundamental principles of serious business undertaking. (Text II)

\section{Extract 8}

Fellow compatriots, I stand before you as a full-blooded Nigerian who belongs to every home. (Text II)

\section{Extract 9}

However, to succeed and to be sustained in office, the next civilian administration must not only arrest and reverse the deterioration, but must also re-activate, re-generate and give a new boost to our economy and public finance. (Text I)

In extract 6, Chief Abiola paints the picture of the socio-economic and political realities of the period. Phrases like daunting challenges and great difficulty, vividly describe the situation and the steps taken so far to find a lasting solution to the problems. The utterance act in this extract is describing. The utterance act in extract 7 is stating and suggesting. Stating is achieved through the verb phrase make bold to say and suggesting is encoded in the split verbal chain must of necessity employ. In stating, the speaker makes reference to the socio-political and economic challenges of the nation and suggests how to arrest the situation. The speaker performs the act of claiming in extract 8. He claims his state of origin and a detribalized Nigerian. In extract 9, Chief Awolowo performs the act of stating. He states the steps needed to be taken by the following civilian administration in order to put the ailing economy of the nation back on track. Consider the import of the coordinator that subsumes the verbal elements, must not only arrest and reverse the deterioration, but must also re-activate, re-generate and give a new boost, in encoding this act of stating. He implicitly inspires his listeners by convincing them that he understands the problems and he has plans to tackle them. The verbs "arrest, reverse, re-activate, and regenerate" describes the decisive actions aimed at tackling the ailing economy and they also reveal the posture of the speaker in solving the problem. Therefore, the speaker performs the acts of stating and inspiring to persuade his listeners to trust him. 


\subsection{Commissive Acts}

In commissive acts, information is supplied regarding the participants' intention to carry out a future action. Commissive acts account for $22.7 \%$ of the total illocutionary acts performed in our data. Such acts include promising, pledging, offering, vowing and swearing. Here are extracts from our data.

\section{Extract 10}

The following declaration of mine is irrevocable under all and any

circumstances namely: I hereby dedicate the rest of my life to the

service of the people of Nigeria, nay Africa, by promoting their

welfare and happiness (Text I).

This extract is a restatement of the speaker's resolve to dedicate the rest of his life to the service of the people. He performs the act is promising or a vowing to be selfless and to promote the welfare of the people in all circumstances. The speaker indirectly refers to the leadership crisis that has negatively affected the fortune of the nation. The utterance act is encoded with the verb dedicate which is pre-modified by the adverb hereby (here and now). The speaker, therefore, performs the illocutionary act of promising or vowing to influence the listeners to accepting him as a candidate who has good intentions towards them.

\section{Extract 11}

I will draw on the confidence that I have cultivated, won and enjoyed

for decades to help move this country forward (Text II).

There are elements of prediction in the use of the verb phrases will draw and will be. The modal auxiliary, will, captures a pre-emptive futurity of the speaker's actions or intentions. Thus, in extract 11, Chief Abiola performs the illocutionary act of promising to do something, the effect of which will be felt in future. This agrees with Dunmire (2005) that commissives are manifested essentially through modal auxiliaries which serve to indicate the futurity of speakers' intentions.

\section{Extract 12}

Hope is what I promise to restore to our country with your mandate to run for president...I am determined to replace doubt with optimism.

I shall renew hope in the Nigerian dream through articulation and pursuit of a new vision of a great Nigeria. (Text II).

In this extract, the speaker performs the acts of promising and swearing. He expressly performs the act of promising with the illocutionary verbs promise and shall renew. The illocutionary force of swearing is implied in the verb phrase determined to replace. The people have lost hope in their leaders and the nation; hence, he promises to restore hope. It should also be noted that the phrases "promise to restore", "determine to replace" and "shall renew" have futuristic implications. There was an atmosphere of hopelessness or despondency in the country caused by the perennial leadership and economic crises which are common knowledge to participants in this context. Therefore, the intention of the speaker in this extract is to convince the listeners of his capability of turning things around in their favour by providing them with good leadership if given the opportunity by electing him president of the nation.

\section{Extract 13}

I declare my preparedness to utilize all the arsenal of resources which it has

pleased the Almighty God to endow me with, for the collective upliftment

of the Nigerian people (Text II).

Chief Abiola exploits his socio-economic background in extract 13 to perform the illocutionary acts of pledging and vowing with such phrases as arsenal of resources and endow me with. He intends to prove to his listeners that he has all it takes to achieve results having succeeded in business and his antecedent as a wealthy philanthropist. The speaker uses the verb declare and the noun preparedness to perform the illocutionary acts of pledging and vowing.

\subsection{Directive Acts}

In directive acts, speakers try to get the hearers to do something. It includes acts of commanding, requesting, condemning, warning, urging, and disagreeing. Directive acts are very few in our data accounting for $18.2 \%$ of the 
total data for this study. Examples in our data include acts of warning, urging and condemning and their force can be identified by recourse to the meaning of the sentences as in extract 14, 15 and 16 below:

\section{Extract 14}

Any rehash of the style of governance of the First Republic, however seeming or disguised, might induce in the people a desire for return to military rule (Text I)

The illocutionary force in extract 14 is warning and urging. The speaker warns against any act of indiscipline and urges his listeners to avoid such acts that could lead to the termination of the following civilian administration. The reference made to the First Republic, which was cut short by military intervention as a result of indiscipline and bad leadership, facilitates our understanding of the illocutionary force of this extract. The noun, rehash, which means to recycle old ideas serve the referential function.

\section{Extract 15}

This fact alone, that is of firm and effective military presence in our public life for more than thirteen years...could afflict the new civilian administration with fear, over-caution or loss of initiative... (Text I)

\section{Extract 16}

So, it is clear that the Executive Presidency of Nigeria is an office which should not be adventured into light-heartedly or recklessly, or with ones' mind suffused and dominated with self-regarding, ethnocentric, or tribal prejudices, predilection and partial affection. (Text I)

In extract 15, Chief Awolowo performs the directive act of warning. Here again, the contextual background of the text facilitates our understanding as he makes reference to incessant military rule in Nigeria. As at 1979, when this speech was delivered, the military had ruled for thirteen of the nineteen years of the existence of Nigeria as an independent nation. He condemns the protracted military rule and the effects it may have on the in-coming civilian administration and warns that it should be discouraged in our political scene. Also in extract 16, the speaker directs his act of warning and urging towards all presidential aspirants of the period to avoid any act that will further compound the problems of the nation. He clearly warns against acts of indiscipline on the part of anybody who eventually becomes the president.

\subsection{Declarative Acts}

The performance of declarative acts brings about a change in the world. These include acts of endorsing, declaring, appointing, naming, resigning, accepting, nominating, and applying and so on. Declarative acts are not common features of acceptance speeches; hence, examples are very few in our data. They account for only $9.1 \%$ of our data. Text I does not have any, while only four examples are identified in text II.

\section{Extract 17}

I accept the mandate, not in a selfish quest for leadership but as a call to service. I accept the mandate with humility and sincerity of purpose as a call to the service of our fatherland (Text II)

Chief M.K.O Abiola accepts the mandate given him as the presidential candidate of his party after his election. The illocutionary act performed here is accepting which serves to encourage his listeners to further support him in winning the election. The speaker also uses the verb accept; to encode his intention (accepting). The act of accepting is achieved with the clause, I accept the mandate (repeated twice). Also the adjective selfish and the nouns humility and sincerity further reinforce this act.

\section{Extract 18}

I hereby reaffirm that all delegates will henceforth be my coordinators in all their respective localities. Letters of appointment to this effect will be distributed as I am speaking to you. (Text II)

The speech from which this utterance was extracted was delivered by the speaker (Chief Abiola) after his election as the presidential candidate of his party (SDP) at the party's national delegates' congress. The major illocutionary act performed in this extract is appointing. The speaker appoints all party delegates as coordinators in their respective localities using the verb phrase will henceforth be. Also, the phrase, hereby reaffirm, is used for emphasis to perform the declarative act of appointing. This, in a way, shows that the speaker acknowledges their (delegates) work and appreciates them. Even though the last sentence in the extract is a promise, the immediate fulfilment (distributed as I am speaking to you) makes it a directive act of appointing. 


\section{Conclusion.}

This study has examined selected political speeches as pieces of discourse with specific goals. It accounts for the structure, meaning and communicative functions of the speeches as naturally occurring utterances produced in particular socio-cultural contexts for the accomplishment of some goals. It presents and documents some of the significant illocutionary acts that convey the intention of the speakers in the selected speeches. The analysis of the two speeches reveals that acceptance of nomination speeches, like Presidential Inaugural Speeches (PIA), are characterised by a preponderance of assertive, expressive, and commissive acts (Adetunji 2009). However, unlike PIA, acceptance (of nomination) speeches are mostly used as mobilization strategies, especially in political campaign where it is essential for candidates to persuade their listeners towards a desired goal of winning elections (See Cheng 2006). Also, speakers' intentions are communicated either directly or indirectly in their speeches and a single utterance can have more than one pragmatic force tied to it.

Finally, the acts performed in the speeches examined are essentially similar, since they are acceptance speeches. Besides, they share almost the same contextual features except for the time frame between the two speeches (1979-1993) which might have aggravated existing challenges. However, the five speech act types identified in the speeches were encoded more explicitly by Chief Abiola than Chief Awolowo.

\section{References}

Adegbite, Wale. (2000). Pragmatics: some basic principles and procedures. In Babajide (Ed.), Studies in English Language. Ibadan: Eni Crown Fit Publishers.

Abiola M.K.O. (1993). Hope '93: farewell to poverty. Lagos: Eminent Comm.

Adegoju, Adeyemi. (2005). A stylistic study of the speeches of some key actors of the 'June 12' crisis in Nigeria (1993-98). Unpublished Ph.D. Thesis, Ibadan.

Adetunji, Akin. (2009). Speech acts and rhetoric in the second inaugural addresses of Nigeria's President Olusegun Obasanjo and America's President George W. Bush. In Odebunmi. A, Arua. E and Arimi. S. (Ed), Language, genre and politics. (A festschrift for Y.K. Yusuf). 275-296.

Babatunde. S and O. Odepitan. (2009). Pragma-Rhetorical Strategies in selected speeches of Olusegun Obasanjo. In Odebunmi. A, Arua.E and Arimi.S (Ed.), Language, gender and politics. (A festschrift for Y.K. Yusuf) 275-296.

Austin, J. L., (1962). How to do things with words. 2nd Edition. In Jo Urmson and Marina Shisa (Ed.), Cambridge, Massachusetts: Harvard University Press.

Awolowo, Obafemi. (1981). Path to Nigerian greatness. Enugu: Fourth Dimension.

Awonusi, V.O. (1996). Politics and Politicians for Sale: An examination of advertising in English in Nigeria's political transition programme. Studia Anglica Posnaniensia xxx (108-129).

Ayoola, A. Kehinde. (2005). Interpreting Nigerian political discourse: a study of President Olusegun Obasanjo’s July 2005 address to Nigeria's National Assembly. In Papers in English and Linguistics. Vol. 6.

Babajide, S.T. (2006) A speech act analysis of christian religious speeches. In Akin Odebunmi and Adeyemi Babajide (Ed.) Style in religious communication in Nigeria. (48-89)

Bach, Kent and Harnish, Roberts. (1979). Linguistic communication \& speech acts. Cambridge University Press.

Bullock, D.R. (2003). The Iraq discourse of President George W. Bush: reconstructing the Soviet-style threat, justifying American and manifesting unipolar world-view. [Online] Available: http://uscpublidiplomacy.org/pdfs/Dennis_Bullock_thesis.pdf.

Cheng, Maria. (2006). Constructing a new political spectacle: tactics of Chen Shui-bia's 2000. and 2004 inaugural speeches. Discourse and society. 17(5) 583-608. http://dx.doi.org/10.1177/0957926506066297

Chilton, P. (2004). Analysing political discourse: theory and practice. London: Roultedge, Taylor and Francis Group.

Chilton Paul and Schaffner, Chistina. (1997). Discourse and politics. In T.A. van Dijk, (Ed) Discourse and social interaction. London: Sage, pp. 206-230.

Chiluwa, Innocent. (2006). A critical study of language variation and ideological differences in media discourse in Nigeria. Ibadan Journal of English Studies. (87-175)

Daramola, Adeyemi. (2008). Child of necessity: An analysis of political discourse in Nigeria. In Journal of IPRA. Vol.18. No 3 (355- 380) 
Dunmire, Patricia (2005). Pre-empting the future: rhetoric and ideology of the future in political discourse. Discourse and society 16(4: 489-513)

Geoff, Thompson. (2004). Introducing functional grammar. Britain: Hodder Arnold.

Grundy, Peter. (2000). Doing pragmatics. New York: Arnold, Goddart, (1998)

Gumperz, J. John and Hymes D (ed.) (1972). Directions in sociolinguistics: the ethnography of communication. Holt, Rinehart and Winston, inc. New York.

Halliday, M.A.K. (1978). Language as social semiotics. London, Edward Arnold.

Haugh, Michael. (2008). Intention in pragmatics. Intercultural Pragmatics 5-2, 99-110

Joseph, John, E. (2006). Language and politics. Edinburg: Edinburg University Press Ltd. http://dx.doi.org/10.3366/edinburgh/9780748624522.001.0001

Kempson, R. (1986). Semantic theory. London: Cambridge University Press.

Leech, Geoffrey. (1983). Principles of pragmatics. New York: Longman.

Levinson, C. Stephen. (1983). Pragmatics. New York: CUP.

Lyons, John. (1977). Language and linguistics: An introduction. Cambridge: CUP.

Malinowski, B. (1923).The Problem of meaning in primitive language. In Supplement to Ogden, C.K. \& Richards, I.A. The meaning of meaning. New York: Harcourt Brace..

Mey, Jacob (ed). (2009). Concise encyclopaedia of pragmatics $2^{\text {nd }}$ edition. Oxford: Elsevier.

Odebunmi, Akin. (2006). Meaning in English: an introduction. Ogbomoso: Critical Sphere.

Odebunmi, Akin. (2008). Tracking and ideology in political news reporting. In Journal of Political Linguistics. Vol. 26.

(2008b). Pragmatic functions of crisis - motivated proverbs in Ola Rotimi's The Gods Are not to Blame. In Linguistik Online 33. 73-84.

Opeibi, B.O. (2003). A discourse analysis of the use of english in the 1993 presidential election campaigns in Nigeria. An Unpublished PhD Thesis. Lagos

Osisanwo, Wale. (2003). Introduction to discourse analysis and pragmatics. Lagos: Femolus-Fetop Publishers.

Palmer, F. R. (1981). Semantics. New York: CUP.

$\mathrm{Pu}$, C. (2007). Discourse analysis of President Bush's speech at Tsinghua University, China. Intercultural Communication Studies $\quad$ xvi. $205-216 . \quad$ Anline] http://www.uni.edu/iaics/content/2007vlbn1/20\%20Chang\%20pu.pdf.

Skoniecki, S.F and College, E. (2004). Tear apart this speech! A Burkean analysis of Ronald Reagan's "Tear this wall" speech. Young Scholars in Writing: Undergraduate Research Writing and Rhetoric 2:18-28. [Online] Available: http://www.bk.psu.edu/Document/Academics/REARAPARTTHISSPEECH.pdf.

Searle, J.R. (1969). Speech acts: an essay in philosophy of language. London: CUP. http://dx.doi.org/10.1017/CBO9781139173438

(1979). Expression and meaning: studies in the theory of speech acts. London: CUP.

Stubbs, M. (1983). Discourse analysis. Chicago: University of Chicago Press.

Rudyk, I. (2007). Power relations in President Bush's state of union speech. The International Journal of Language, Society and Culture 23:68-76. [Online] Available: http://www.edu.utas.edu.au/users/tle/JOURNAL//issues/2007/23-7.pdf.

Taiwo, Rotimi (2006). Tenor in media christian discourse in Nigeria. In Akin Odebunmi and Adeyemi Babajide (Ed.) Style in religious communication in Nigeria. (90-106)

Thomas, J. (1995). Meaning in interaction: an introduction to Pragmatics. London: Longman.

Van Dijk, T.A. (1995). Discourse Semantics and Ideology. In Discourse and society, vol. 6 (2), London: Sage Publications. (243-287).

Watson, J.R. \& Hill, A. (1993). A dictionary of communication and media studies. London: Edward Arnold.

Wiredu, J.F. (1996). The Style of political communication: The Nigerian experience in the 1979 elections. In Legon Journal of Humanities. Vol.9, (57-80):

Yule, G. (1996). The study of language. Cambridge: CUP. 